\title{
ONLINE ADVERTISING IN NIGERIA: AN EXAMINATION OF APPROACHES IN FACEBOOK AND INSTAGRAM
}

\author{
Silas Udenze (a), Olisa Junior Aduba (b)
}

(a) University of Abuja. Abuja, Nigeria. Email: udenzes[at]gmail.com

(b) University of Abuja. Abuja, Nigeria. Email: adubaolisa[at]yahoo.com

\begin{abstract}
The study examined online advertising in Nigeria; it also sought to ascertain an examination of approaches in Facebook and Instagram. The aim of the research is to analyse the extent Nigerian businesses are utilizing social media to advertise their products. The theory adopted to anchor the study is Diffusion of Innovation Theory. Mixed methodology was employed to generate data for the study. Survey designed was used for the quantitative method while semi-structured interviews were conducted for the qualitative method. Online questionnaires were employed to get data from 375 Internet-users; representing consumers of these online advertisements, while 6 business owners making use of online advertising through social media, were interviewed under the qualitative method. The results of the study show that Nigerians make use of social media sites like Facebook and Instagram as advertising platforms to a little extent despite the huge number of consumers using these networks in the country. The research recommends that business owners should change their perception about social media as just a platform for fun or social activities, but to start considering it as an avenue to marketing and profit making. Also, the work recommends Nigerian businesses to engage the media professionals to handle their online activities; taking into the account that social media is so powerful it can build or destroy any business or brand. The work further recommends more effort put into the Consumer Protection Council with regards to online advertising activities. This will aid to online consumers protection and also to a large extent curb the cyber fraud.
\end{abstract}

\section{Keywords}

advertising; Facebook; Instagram; Nigeria; Social media; media; communication

This work is licensed under a Creative Commons «Attribution» 4.0 International License. 


\title{
ОНЛАЙН-РЕКЛАМА В НИГЕРИИ: ИЗУЧЕНИЕ ПОДХОДОВ В FАСЕВООК И INSTAGRAМ
}

\author{
Удензе Силас (a), Адуба Олиса Джуниор (b) \\ (а) Университет Абужа. Абуджа, Нигерия. Email: udenzes[at]gmail.com \\ (b) Университет Абужа. Абуджа, Нигерия. Email: adubaolisa[at]yahoo.com
}

\section{Аннотация}

В исследовании рассматривается интернет-реклама в Нигерии; в частности, ситуация с рекламой в социальных сетях Facebook и Instagram. Цель работы изучить, в какой степени нигерийские предприятия используют социальные сети для рекламы своей продукции. Теоретической основой исследования является теория Диффузии инноваций. Смешанная методология была использована для получения данных. Разработанный автором опрос использовался как количественный метод исследования, в то время как полуструктурированные интервью проводились для качественного метода. Онлайн анкетирование использовалось для опроса 375 интернет-пользователей, представляющих потребителей рекламы, в то время как 6 владельцев бизнеса, использующих рекламу через социальные сети, были опрошены в рамках качественного метода. Результаты исследования показывают, что нигерийцы слабо используют социальные сети, такие как Facebook и Instagram, в качестве рекламных платформ, несмотря на огромное количество пользователей этих сетей в стране. В исследовании рекомендуется, чтобы владельцы бизнеса изменили свое восприятие социальных сетей как просто платформы для развлечения или социальных мероприятий, и обратили внимание на предоставляемые ими возможности для маркетинга и продаж. Кроме того, работа рекомендует нигерийским предприятиям привлекать профессионалов СМИ для управления своей онлайн-деятельностью; учитывая, что социальные сети настолько мощны, что они могут создать или разрушить любой бизнес или бренд. Далее автор рекомендует Совету по защите прав потребителей приложить больше усилий в отношении онлайн-рекламы. Это поможет защитить онлайн-потребителей, а также в значительной степени обуздать кибер-мошенничество.

\section{Ключевые слова}

реклама; Facebook; Instagram; Нигерия; социальные сети; медиа; коммуникации

\footnotetext{
Это произведение доступно по лицензии Creative Commons «Attribution» («Атрибуция») 4.0 Всемирная
} 


\section{INTRODUCTION/BACKGROUND TO THE STUDY}

In recent times, the advertising landscape has evolved significantly especially online over the internet. Citing Dominick (2007) Asemah, and Edegoh, defined Advertising as "any form of non-personal presentation and promotion of ideas, goods and services, usually paid for by an identified sponsor" (2013, p. 321). Further, in justifying the essence of advertising, they equally argue that "Advertising is unique and special and if anything is to be known about the existence of a product, commodity, item, good, service or a political candidate, etc., and then there is the need for advertising". Asemah, and Edegoh, (2012, p. 251). In the past, Organizations usually purchased advertising time slots on television or radio, spaces in newspapers, and best locations for their hoardings on the busiest of streets. However, still couldn't get directly in touch with their target consumers. After the arrival of this new media, a new dimension was introduced to human communication called online advertising, leading to the complete change in the pros and cons of advertising. Online advertising can be said to be adverting on the internet.

Online advertising, simply put, is advertising on the Internet. Online advertising cuts across display adverts found on websites, adverts on search engine results pages, adverts found in emails and other social platforms, and different ways in which advertisers use the Internet. Of course, this is not just limited to computers; online advertising can be found anywhere you access the web, for example, through mobile devices, I-pads, tabs, etc. One primary objective of online advertising is to increase brand awareness or information without geographical boundary limits. One of such dimensions is the social media. Social media are social interaction designed platforms. They are sites that enable user participation and allow individuals or groups to generate content and engage in conversations and exchange of materials. Andres Kaplan's perception about Social media as cited by Endwell, (2014, p. 1) states that "online media that promote participation, openness, conversation, community, connectedness, interactivity, collaboration and information sharing".

According to Kaplan, and Haenlein, (2010, p. 61) Social media build on the ideological and technological foundations of Web 2.0, which allows for collaboration and the creation and exchange of user-generated content". Arens, Weigold and Arens, (2011) as reviewed in Endwell, (2014) argues that social media platforms are called social, mainly because they possess the ability to connect like-minded individuals in such ways that have never been experienced before. Endwell $(2014$, p.2) goes ahead to 
opine that "Social media allow people to exchange personal comments, political views, business ideas and commercial messages using various online platforms such as blogs, microblogs and social networks."

Similarly, Eid, and Ward, (2009) as cited in Endwell, (2014) agree that in this modern age of the information superhighway, significant numbers of people around the world are building social networks online that cut across local, regional and global communities thereby communicating "their shared interests and activities", and interacting through a number of online-based tools.

It is challenging to study social media without encountering the phrase social networking. Hence, both concepts will be discussed in this study. Weltge, and McKenzie-Harris, (2017, p.15) define social media as any medium of communication performed electronically through which users start-up online communities to share information, ideas, personal messages, and other content (as videos). While Investopedia defines social networking as" the use of internet-based social media programs to make connections with friends, family, classmates, customers and clients. Social networking can happen for various reasons, example business purposes, social purposes or both through applications such as Classmates.com, Facebook, LinkedIn, Twitter and Yelp." A simple way to comprehend the essential difference between social media and social networking is that people are assisted through social media to make the connection while social networking enhances that connection. People are linked together due to their "common interests, passions, and causes" as they continue to enhance their relationships by getting to know each other through interaction over time (Cohn, 2011).

The increasing rate of growth of these social media has made it impossible for them to be ignored by individuals and business organisations (Omeruo 2010). Giving credence to the above, Osae-Brown and Emelike (2011) note that social media are changing the manner many businesses communicate with their customers. In like manner, consumers are using the social media to take charge of their shopping experience and connect with others. They explain that these social media have become an instantaneous marketing tool used by ambitious advertisers to improve awareness about their products and services; thereby building a strong online presence and community.

Dominick (2009) explains that advertisers mainly showcase their products/services on social networks and use platforms such as blog ads to target specific blogs whose readers would be likely customers. Some advertisers also have links or hyperlinks below their adverts linking potential customers to their web pages, blogs or social networking plat- 
forms. According to Nnanne, (2011, p.5) Social media are "undoubtedly shaping and redefining the nature of communication among people all over the world." This statement aligns with Endwell, (2014, p. 2) position that the attraction to social media by business organisations/entrepreneurs is that barriers are broken as they can relate to customers on a one-on-one basis.

In the past, advertising used to be seen as a one-way communication, delivered from the advertiser through some media vehicle to a receiver, the target audience. This also means that advertisers hardly hear what consumers are saying about their products unless they embark on research. In a world with Web 2.0 (social media), advertising encounters a new phase. Social media enable interactive capabilities in an environment characterised by user involvement, "freedom, and dialogue" thereby bringing about a high degree of interactivity and consumer involvement in advertising applications. Online advertising through Social media has genuinely enabled a two-way (or multi-way) communication between brands and consumers. "Social media, blogs and microblogs have made it possible for consumers to express their opinions and experiences about a product" (Arens, Weigold and Arens, 2011, p. 552). Online advertising becomes more about connections, conversations, and shared control resulting to less passive consumption of packaged content. Dominick, (2009) argues that advertising is not only paid for in this era but word of mouth (viral advertising) is used to harness paid advertising.

Advertising through traditional media relied on a model of interrupting and disrupting consumers life. This interruption is because the key to every ad is to halt "what the viewers are doing in order to get them thinking about something else" (Chaney, 2009, p.37). Consequently, scholars believe that consumers accept these interruptions, served in the form of advertising, because they recognised it as a price to pay for what was formerly seen as free content on the electronic and print media. In other words, dominant content owners determined the dissemination of content targeted at consumers. The interruption-disruption model is being eliminated by the social media, which enables consumers to control and create their own media content.

According to Diamond (2010), the paradigm shift is a change of power. Customers do not only want to be asked permission by marketers, but they also want to engage actively and be involved in the ideas contributing to a product. They desire to tell a company what they feel, how the consumers view their brand, and how they can improve. Evans \& Mckee (2010, p.11) explain that - engagement on the Social Web means that customers become participants rather than viewers. Online advertising 
through Social media has granted consumers the authority to speak up, and their voices are being heard loud and clear. While organisations want consumers to buy their products, these empowered consumers wish that the companies pay attention to them and give an opportunity to contribute to decision making. They no longer want to be mere passive consumers of products and services, but active participants helping to co-create them (Chaney, 2009; The Economist 2006). Praise and Guinan (2008) posit that for social media advertising to thrive, an organisation's marketing department should relinquish some level of control and instead facilitate customers in driving the organisation's value proposition.

This study will be focusing more on social networks like Facebook and Instagram. Facebook and Instagram give business organisations the opportunity to meet their target markets as well as afford individuals the opportunity to connect with the organisations and brands they like and learn more about their products and services.

On Facebook, subscribers connect to a brand by "liking" them. While on Instagram, an individual "follows" a company of choice to get posts from them. Diamond (2008) explains that "individuals want to do business with people they like, so a company needs to be likeable". Facebook advertising platform is known as Facebook Ads. Tuten (2008) explains that Facebook has offered advertisers more strategic value with a mix of essential avenues, including targeted display ads and sponsored stories, known as Social Ads, branded profiles known as Facebook Pages, a developer incentive program to encourage content development called Facebook Developers, and Newsfeed. He notes further that Facebook Social Ads are targeted at specific users based on member profiles and behaviour in the network. For instance, adverts on Facebook can be delivered to users whose friends have recently engaged with the brand's Facebook profile or visited the brand's website. Even the destination of delivery for social adverts can be set with adverts appearing next to News feeds of friends (a Facebook feature that gives room for friends to update others on their latest activities). By delivering ad impressions that are corresponding to news feeds, Facebook encourages word-of-mouth communication and interaction about a brand.

Adverts on Instagram are called Instagram ads; they show up as sponsored posts on your page. One has access to freely remove ads, which they feel is not relevant to them by directly going to the menu and removing that particular ad. The consumer also has the option of including advertisements that they have interests in and also get involved with an Instagram community with same likes. Just like Facebook (their parent company) the app chooses the ads to show the user based on the information 
of what you do both on Facebook or Instagram and by third-party sites and apps. For example, you might see ads on your page based on people you follow and things you like on Instagram, your information and also interests on Facebook (if you have a Facebook account with the same details) and the websites you visit and the apps you use.

However, it is just as important to understand the motivation behind why people use social media (Facebook and Instagram) as it is to know how they serve as very effective online advertising platforms. This development exists because while much is uncertain about social media, one thing is sure, the masses have widely adopted them. Therefore, this study examines the utilisation of online advertising in Nigeria with approaches in Facebook and Instagram.

\section{STATEMENT OF THE PROBLEM}

Since the coming of Facebook and Instagram, a growing number of commercial organisations have embraced them as part of their marketing strategy. They have uncovered the potentials of the social media in promoting customer relations and increasing product patronage. Being that social media is a new platform for advertising and is still underutilised; the percentage of active users, entrepreneurs/business organisations that have embraced this new platform completely, is currently not known. It is also not known how entrepreneurs/businesses using them have fared regarding improved patronage. With over 93 million internet data subscribers, stated by the Nigerian Communication Commission (NCC) as at October 2017, 16 million monthly active Facebook users as of June 2016 in Nigeria and four million, two hundred thousand, six hundred and fourteen $(4,200,614)$ fans generated from Nigeria. The researchers wanted to establish whether Nigerians are participating in the growing phenomenon. Are they using Facebook and Instagram as strategic online advertising platforms? Are business organisations/entrepreneurs utilising the advantages of this "ready" and substantial social market to relate with their clients on an individual level?

\section{AIMS AND OBJECTIVES OF THE STUDY}

The study's primary aim is to examine the use of online advertising in Nigeria, examining the approaches in Facebook and Instagram. The secondary objectives of this study are: 
1. To establish the what extent to which social media sites like Facebook and Instagram are used as advertising platforms in Nigeria by Nigerians.

2. To find out the impact of the online advertisement to consumers of social media platforms

3. To ascertain to what extent social media advertising is beneficial to business owners.

4. To determine the level of success in promoting products through online advertising.

5. To examine the challenges business owners encounter in the use of social media for advertising.

\section{RESEARCH QUESTIONS}

These research questions were formulated to direct the study:

1. To what extent are social media sites like Facebook and Instagram as advertising platforms in Nigeria?

2. What are the impacts of the online advertisement to consumers of social media platforms?

3. What extent is social media advertising beneficial to business owners?

4. What is the level of success in promoting products/ services through online advertising?

5. Are there any challenges limiting the effective application of online advertising in Nigeria?

\section{LITERATURE REVIEW: ONLINE ADVERTISING}

Online advertising can be called by the following names: online marketing, Internet advertising or web advertising. Falah (2014) believes this is a type of advertising and marketing which makes use of the Internet to deliver promotional oriented messages to potential consumers. Belch \& Belch (2001) saw advertising on the web as a variety of forms, which includes banner-advertisements, interstitials, pop-ups, sponsorships, and links or webcasting push technologies. The study of Baran (as cited in Mathew, Ogedebe and Ogedebe, 2013) sees "web advertising as cyber advertising; they are interstitial ads, pop-outs, extramercials, large rectangles, advergames, intermercials, transaction journalism, text ad, targeted keyword buys and surround sessions."

According to Dominick (2009), October 1994 was the beginning of online advertising, when Hotwired, the first digital commercial magazine, 
began a network with some sponsors who subscribed by paying to acquire advertising banners for their products placed on the entire the sites.

Lisica, Jesic and Neskovic (2012) saw advertising online as a kind of promotion which employs the internet as a medium to convey marketing information with the aim of attracting patronage. According to Adikesavan (2014), an example of online advertising include online classified advertising, blogs, and banner ads, contextual ads on results pages of search engines, advertising networks and interstitial ads. Gordon and LimaTurner (cited in Mathew, Ogedebe and Ogedebe, 2013) were of the opinion that a social agreement between internet users and advertisers could be seen as online advertising.

Choi and Rifon (2002) urged that the fast growth of revenues generated from online advertising show the capability of advertising online as an alternative to that of conventional media. Hwang, McMillan and Lee (2003) stressed that advertising online is not just pop-ups and banners buttons, but also believe that website for businesses includes an essential functionality missing in the conventional corporate advertising. The possibility of designing eye-catching, innovative, unique and self-perpetuating advertisements is limitless. When developing an online ad, content, colour, style, graphics, format and the target audience must be put in perspective for the advertising message to be communicated effectively and efficiently. By understanding and implementing the best-suited design features, a company can produce effective campaigns that reach target audiences, and go beyond standard demographic groupings. Online advertisements can be designed strategically, with the goal in mind of achieving, and influencing a particular target market (Gallagher et al., 2001)

Wohn and Korgaonkar (2003) said that there is a massive difference between how male and female genders perceive online advertisement. Positive attitudes towards adverting online are seen in the males than females. Another is that the men have a higher tendency than the female gender to buy from the internet. The men surf the net for entertainment and functional purposes, which has a higher tendency to encounter online advertisements unlike the majority of the female that most times settle for shopping purposes.

Mathew, Ogedebe and Ogedebe (2013) also believed interactive technologies like the internet created the opportunity make advertisements that are more personal, more targeted and yet is capable of carrying the audience to participate, thus feeling engaged. This is to say that as a medium of advertising, it provides an excellent opportunity for engaging, interacting and captivating the users. An array of various formats of advertising can be employed to convey a specific message to audience Ac- 
cording to Brigg and Holis (1997) the different forms of advertisement acquire different types of responses from the audience, meaning each format of the online advertisement has its peculiar attractions and limitations.

\section{NEW MEDIA}

New media are digital technologies, with attributes of being interactive, compressible, manipulated, dense, and networkable. A few examples are the computer multimedia, Internet, CD-ROMS, computer games, websites and DVDs. In other words, unless a technology contains such features that are capable of digital interactivity, it cannot be termed as one.

New media creates an avenue with the possibility for any user to design, edit, remodel and exchange contents with other users, making use of tools that are easy to use and most times they cost little or nothing. The essential requirement for the new media is a mobile device or computer with access to the internet. The following are what the new media can do:

i. Link people with information

ii. collaborating with others, this includes members of your network;

iii. Creation of new avenues of communication that assist in delivering information

The new media are a disparate set of communication technologies that share specific features apart from being new, made possible by digitisation and being widely available for personal use as a communication tool. The new media is not only or even mainly concerned with the production and distribution of messages, but at least, mostly involved with processing, exchange and storage. The new media can be considered as much an institution of private, as of public communication and are regulated but not accordingly. Their operations are not typically professional or bureaucratically organised to the same degree as mass media. These are the significant differences that underscore the fact that the new media correspond with the mass media primarily in being widely diffused, in principle available to all, for communication and at least, as free from control.

Newness is a relative characteristic, as both place and time influence the technology; this is to say, what can be classified as new today, can also be tomorrow termed as old, and what is perceived as new in one's surroundings or culture can be seen as outmoded or unknown in another. 
Thus, newness at some point was seen as the application of telecommunications, microelectronics and computers that renders new services or amplifies the old ones. It merely means that the very moment technologies are created to complement or succeed the old ones in performing better, then such platforms can be classified as "new media ". According to McQuail's study, (cited by Asemah and Edegoh, 2012), New media has four main characteristic attributes. They are as follow:

i. Encoded content decentralisation;

ii. higher capacity with regards to dissemination, which has surpassed limitations of the past like capacity, cost and reach;

iii. interactivity; giving room for receivers to be more active and participatory in the flow of information; and

iv. Flexibility.

\section{SOCIAL MEDIA}

Social media's concept has attracted so many perceptions and views from various disciplines. A necessary explanation connotes "interactive communication within a group". The "group" in this definition represents "social" content of the definition. According to Suomen Toivo-Think Tank (2012), social media are new information network and information technology using a form of interactive communication skills, where users produce the content of information and interpersonal relationships are established and maintained in the process. A typical social media services could be content sharing, web communities, or an Internet forum (Sanastokeskus, 2010). In the same vein, Kaplan and Haenlein (2010) identified social media as a group of Internet-based application that is structured on the technology and perception of web 2.0, which gives access to create and exchange its content. Sweetser and Laricsy (2008) believe that users of the social media are not passive like in the situation of radio, Television, magazine and Newspaper; preferably they are active in generating and exchange of information.

Social media make use of technologies that are web-based, computer and mobile devices (examples are palmtops, tabs, desktops, laptops and smart-phones) for the creation of highly interactive forums giving access for persons, communities and or businesses to exchange, discuss, refine content that is generated by the users.

According to Ace Cloud Hosting (2015), Social media functions in a dialogic transmission system (many sources too many receivers). Which makes it the opposite to how conventional media functions, traditional 
media functions under a monologic transmission model (a single reference too many receivers), an example is a paper newspaper which is conveyed to many subscribers. Facebook, Instagram, WhatsApp, LinkedIn, Google+ Pinterest, Twitter, Reddit, Viber, Snapchat, WeChat, YouTube and Tumblr are favourite examples of social media platforms. With each of them having more than 100,000,000 registered users.

\section{SOCIAL NETWORKING SITES}

Social Networks were defined by Redbridge Marketing (2008) people within online communities who practically exchange in their activity, a unified interest. According to YALSA (2007), Social Networking Sites can be seen as "those websites which give an opportunity for interaction, by allowing you and other users to post content, building on the web's data and partaking in a live chat. Marketing Evolution (2007) observed that Social Networking stands for :

A fad, especially among the young and technologically obsessed an unprecedented tool for keeping in touch with friends and family "A disruptive, unscripted environment" An unparalleled opportunity for brands and consumer to make genuine connections" Some combination of all of the above .... and then some.

The research document from the Office of Communications (OFCOM) saw Social Network sites as those platforms which give users the opportunity to create their information page like a personal page and also room to build their network. This explanation further suggests that social networking sites are forums not just based on social interactions but is also an avenue for business relationships between customers and companies. Social Networking Sites are many, but the most popular ones are Skype, Facebook, WhatsApp, YouTube, WeChat, Instagram, Twitter, Reddit, Vine Camera, Pinterest, BBM, Tumblr, Google+, Linkedin, Viber, Kakaotalk. Facebook has about 1.97 billion monthly active users as of April 2017, while WhatsApp (1.2 billion) and YouTube (1billion) follow in a suit regarding popularity among the list (Statista, 2017).

The process of Social Networking is straightforward, in the sense of no need for a compulsory complex set up like special training of graphic or web design is required. This is to say posting on forums, creating blogs, adding content on a friend' wall, editing information on wiki and watching or creating a channel on Youtube is very simple to perform; and it is even getting more comfortable by the day as manufacturers are modifying it, no wonder there is a constant increase in youths participation. 
Examples of social networking tools according to the research document from Social Networking Tools Office of Communications (OFCOM) are Blogs, Podcasts, RSS, Tagging and wiki. According to Marketing Evolution (2007), social networks are classified into the following: The Professionals, the See and Be Seens, the Connectors, the Explorers, the Rookies, and the Spectators.

OFCOM (cited in Gbadeyan, 2010) also categorised people due to their attitudes and behaviour in using social networks, and they are The "Alpha Socializers", the "Attention Seeks" the "Followers", the "Faithfuls" and the "Functionals." OFCOM also categorised non-users of the social networking sites into groups for various reasons, they are:

1. Intellectual rejecters - They have no interest for it because they see it as a waste of time.

2. Concerned about Safety - They are worried about the how secure are their details online, therefore having doubts on making use of it

3. Technically experienced - They do not believe in making use of technologies like computers and the internet.

\section{FACEBOOK}

The social network platform Facebook merely is used for the connection users with people surrounding them, these can be family members or relations, friends, colleagues or other people with interests that are similar. In 2004, Mark Zuckerberg along with Austin Moskovitz, Chris Hughes and Eduardo Saverin created Facebook. Initially, there was a restriction to the membership for Facebook. Only students from Harvard had access to get it; however, the membership was later extended to students from other colleges/ universities across the United States. According to Dunay and Krueger (2010), Facebook expanded in 2006 not just beyond universities, but to businesses, other schools and users interested around globally.

According to Nwaeze, (cited in Nyekwere, Kur and Nyekwere, 2013), believes that advertising on Facebook gives room for businesses to reach their exact customers, linking them to their brands and products. Of recent, there have been some additions of new features to Facebook which includes Story sharing, instant chat/messaging, live video etc. Users of the platform can communicate with other users through various methods, for instance, video calls, private messaging or merely writing on walls of other users. Posting on Walls by default cannot be seen by the general public but only the friends of the user. Privacy settings can also be ad- 
justed by a user to allow others to visualise his profile, from the level of friendship already existing.

Facebook gives a platform for businesses, brands, products, and professionals in all spheres of life, celebrities, public figures and individuals with the aim of showcasing themselves to the Facebook community. According to Facebook newsroom (2017) as of December 2016, Facebook has an average of 1.23 billion daily active users worldwide and 7.2 million people in Nigeria visits Facebook each day (Financial Nigeria, 2016), although in the past consumer brands that are big enjoy having large fan bases due to their reach, but this day, smaller brands, personalities and consultants can also develop a loyal and massive fan base by making practical use of Facebook. "If Facebook were a country, it would be the most populous nation on earth. With a size of 1.39 billion people logging in to Facebook each month to go through their News Feeds, communicate with various groups and friends and then engage in other activities in the platform." (Stenovec, 2017). That exceeds the entire population of China, which is the world's most populous country. According to Taylor (2016), at least two people in seven of the world's population make use of Facebook monthly.

Facebook stated from Nigeria alone, daily users amounted to 7.2 million people, with a large percentage accessing the platform via mobile. According to a study done in 2017 by eMarketer, $42 \%$ of millennial respondents admitted that they had not stayed up to five hours without checking their feeds.

The top four platforms used by social media marketers include Facebook, LinkedIn, Instagram and Twitter, with the pack led by Facebook. Social Media Marketing Industry Report (2017) stated that a total number of 94\% was the number of marketers making use of the platform, Facebook. It also revealed that $62 \%$ of the marketers picked Facebook when asked to select their most important platform. According to an info-graphic by Sumo Coupon, Facebook users generate 4 million likes every minute. Also, every 60 seconds, the following are achieved: 500 new users join Facebook; 50,000 links are shared on Facebook; 100,000 friend requests are sent; 243,000 photos are uploaded on Facebook; and 3, 3 million items are shared on Facebook.

Facebook Pages are user profiles equivalents. A page is a location on the site where entrepreneurs/companies write all about themselves. Some of the most robust social targeting features, as noted by Zarrella and Zarrella (cited in Endwell, Tur and Nyekwere, p.183. 2013), are useful when such companies have a large number of Page members or users. Zarrella and Zarrella notes further that although some brands attract mil- 
lions of fans to their Facebook pages through paid advertisement, there are also some brands that their marketing strategies capitalize on the viral power of Facebook, relying on fan participation to generate a stream of news feed stories, which in turn create word-of-mouth awareness and attract new fans to the page. Special events such as symposium, trade fair, seminar etc., can be generated by an organisation on their official page and "invitations" delivered to friends on their network. According to Endwell (2012), while commercial messages posted on a company's Facebook page and their events are restricted to their fans, the paid advertisement appears on the right-hand side of a Facebook page whose owner falls within the target market of the advertiser as indicated during the creation of the advertisement. Pages can help a company promote their business on Facebook through the following:

Wall: this is similar to a user's profile; it is in the form of a tab which serves as the central component of a Facebook page. The Wall gives room for a business brand and their followers to post data like notes photos and videos. Updates are being generated from these actions and most times displayed on a user's news feed as stories.

News Feed: this section of Facebook displays any recent activity taking place on a user's or business page. For instance, once there is a new video posted on a user's page, it is published on his or her news feed as a recent story.

Status Updates: this gives the avenue for one's status to be updated; this is an attractive tool for marketers as it provides room for a marketer to input any new information about their products. Unlike the profile section, this tool accommodates endless streams of updates conveyed to your followers.

Discussions: this is a tool in which topics are expanded through conversations. Users start up a topic and followers are allowed to build on it by commenting their opinions. Two options are usually given for followers which is a box to write on or a button to click like. Facebook assists in solidifying relationships irrespective if the organisation is advertising to other organisations or persons.

As of March 2016, according to the growthok blog (2017) stated that three million companies, as of March 2016, from all over the world used Facebook's paid ads to reach their target audience, with more than $70 \%$ from outside of the United States. In April 2017, the number had grown to 5 million advertisers. The majority of Facebook's advertisers are small and medium-sized businesses. A report by Social Media Examiner in 2017 revealed that a surprising $93 \%$ of social marketers regularly use Facebook ads and $64 \%$ plan on increasing their Facebook ads activities. 


\section{INSTAGRAM}

Instagram is a social networking application that mainly deals with mobile photo-sharing, Kevin Systrom and Mike Krieger created the app. It was launched in October 2010 it was designed primarily for only Apple products for free but was later released two years later for Android devices. It was bought by Facebook in April 2012, for US $\$ 1$ billion. Just a year after, Instagram grew by $23 \%$, while Facebook, being the parent company, only increased by $3 \%$. Instagram has three primary sections, which are:

Camera: this is the part of the app where the user can post pictures or videos; editing and filtration of the photograph or video can also be done here. This is the section basically where one selects what to post to the public. What will be seen about you.

Instagram page: this is the section where you see what others have posted; it can be videos or just pictures. This is the section where the audience gets to see what a company is advertising. The audience can communicate back by "liking" the picture or video," commenting" or "send to" other users or groups.

Direct: this is the section where you view posts you have sent to other users or groups. Recently this section was updated, and one can now send disappearing posts like photos and videos to others or groups.

Updates and new features are steadily released on Instagram to enhance more spontaneous and frequent sharing within the application, one of them is the "Stories" feature, which can be identified as a replica of Snapchat's core feature. This gives room upload multiple pictures and videos with filters and illustrations. According to Forbes, as of December 2016, Instagram has about 600 million active users monthly. The social network has been focusing on growing its global advertising business and enabling more real-time sharing. After first launching advertising widely about a year ago, the app reached 500,000 advertisers in September. Instagram was expected to generate about $\$ 1.5$ billion in mobile advertising sales in 2016 and the estimate of $\$ 5$ billion in 2018, according to forecasting firm eMarketer. (Czajkowski 2016).

Ads on Instagram are called Instagram ads; they show up as sponsored posts on your page. One has access to freely remove ads, which they feel is not relevant to them by directly going to the menu and removing that particular ad. The consumer also has the option of including advertisements that they have interests in and also get involved with an Instagram community with same likes. Just like Facebook (their parent com- 
pany) the app chooses the ads to show the user based on the information of what you do both on Facebook or Instagram; For instance a user may see a particular type of advertisement on your page based on things you like on the application and people you follow on Instagram, your interests and also information on Facebook (if you have a Facebook account with similar details with that of Instagram); the websites you visit and the Apps you use.

\section{THEORETICAL FRAMEWORK}

Theories are very relevant in every academic endeavour. Thus, Asemah (2010) emphasises that theories lend themselves to various analysis and texts, such that the phenomena central to the research get clarified, explained and even predicted as the case may be. Therefore, for us to attain a clearer grasp of this study, the diffusion of innovation theory has been selected to provide the framework.

The theory diffusion of innovation is best described as how information or idea can spread over time through some channels and social structures in the society Ojobor, 2002. Also, it can be seen as the process by which that innovation is communicated over time through certain mediums between the members within a social system; in other words, the concept behind this theory is that for a new idea to spread there must be awareness stage, interest stage, the evaluation stage and trial and adoption stages. Rogers (1962) and Rogers and Shoemaker's (1973) model of information diffusion envisaged four stages: information, persuasion, decision or adoption and confirmation (McQuail, 2011). To this work, the theory's relevance stems from the fact that social media are at the evolving stage and as such, different users will adopt them in varying degrees. While some users have passed awareness, interest and trial stages, choosing social media for advertising and some patronising products advertised on them, others are yet to embrace this new media even though they are aware of them.

\section{METHODOLOGY}

The study adopted dual methodology, that is, qualitative and quantitative method. The qualitative method, focus group was employed for the selected companies: The Companies whose staffs were selected for the interviews are: "Tribal chic" Known with the handle" the_tribalchic" on Instagram and "kevwee" on Facebook; it focuses on fashion and designing, located in Abuja; it has over five hundred and seventy followers on both Facebook and Instagram. "Lemmy Vendutti Photography (LVP)" is a me- 
dia company that deals in photography for various events and personal portraits, located in Abuja, it has currently twenty-five thousand three hundred followers $(25,300)$ on Instagram and eighteen thousand, and seventy-nine $(18,079)$ followers on Facebook. Finally, Sapphira Island known for the sale of cosmetics, make use of both the Facebook and Instagram platform to advertise, they have one thousand seven hundred and sixtynine $(1,769)$ followers on Instagram and five hundred (500) on Facebook. They were considered because of the ample experience they have gained in operating their businesses. Successfully advertising their products and services on various social media platforms and interacting with the clientele.

The quantitative method, survey was used to explore the thoughts of residence of Abuja. Abuja is Nigeria's Federal Capital Territory and a cosmopolitan City, bringing together people of diverse cultures, tribes, states and ethnicities from all over; which automatically represent the entire country. Abuja is broken into Abaji, Abuja Municipal Area Council, Bwari, Gwagwalada, Kuje and Kwali. According to Adeyemi Adepetun of the Guardian Newspaper, the National Bureau of Statistics telecommunication sector's third quarter 2016, stated that Abuja has a total population of 4,359,372 internet users, thus in determining the sample size, this population was adopted using Taro Yamane (1976) method for calculating sample size. The equation is illustrated as below:

$$
\begin{aligned}
& n=\frac{N}{1 N \cdot(e)^{2}} \\
& \mathrm{n}=\text { Sample Size } \\
& \mathrm{N}=\text { Population under study } \\
& \mathrm{e}=\text { Margin of error or level of precision (it could be } 0.10,0.05 \text { or } 0.01 \text { ) } \\
& \text { Therefore, when this formula is applied with the combined popula- } \\
& \text { figure of internet users in Abuja, which is } 4,359,372 \text { we get the fol- } \\
& \text { ing: } \\
& n=\frac{4,359,372}{1+4,359,372 \cdot(0.005)^{2}} \\
& n=\frac{4,359,372}{1+4,359,372 \cdot(0.0025)^{2}} \\
& n=\frac{4,359,372}{10,899.43}=\mathbf{3 9 9 . 9 6 3 3 ~ 0 0 8 ~ 3 3 2}
\end{aligned}
$$$$
\text { Therefore, when this formula is applied with the combined popula- }
$$
tion figure of internet users in Abuja, which is 4,359,372 we get the following: 
A sample size of 400 was adopted from the calculation.

\section{ANALYSIS OF QUALITATIVE DATA}

In analysis the qualitative data that emanated from the interviews study, the researcher analysed the data thematically. After a thorough coding of the six interviews, some major themes emanated, thus, the analysis of data in this section is done thematically. It is pertinent to state that the analysis of data is done in consonance with the research objectives of the study.

\section{A popular media: Facebook and Instagram}

One of the secondary objectives of this study is to ascertain to what extent social media platforms like Facebook and Instagram are used for advertising. To answer this question, six companies were purposively chosen, and these companies use Facebook and Instagram for advertising. This is a pointer to the fact that Facebook and Instagram are obviously popular. From the analysis of data, it was revealed that business owners are coming to the realisation that social media is paramount to the success of their businesses. Participants of this study also revealed that they have been using the social media for advertising for more than five years now. According to a respondent, Ossia Okey who was interviewed on the 20th May, 2018, "Ok, I have been in business for more than twelve years but started advertising online five years ago when I saw the trend, because without social media you won't go far in business, won't have 360 degree view of your business, people won't know about your business, but with social media, you will be like you are in the global village, everybody no matter where they are, will have access to you". From the latter assertion, we can observe that the respondent has been using the social media for up to five years now. The participant above also revealed that without the social media a business venture might not fully achieve its mission and vision. Since all the interviewees of this study use Facebook and Instagram for their advertising, this finding concludes that business owners use social media platforms for advertising purpose to a large extent.

However, it also discovered that social media the use of social media for advertising is still at the infant stage in Nigeria. All the interviewees of this study are of the opinion that social media advertising has not reached its zenith. They profess that business owners have to come to the realisa- 
tion that social media has the potential to change the fortune of businesses. According to Ahmad Amin, a respondent that specializes in photography, "No, it has not and it is just starting, a lot is going to come up from it, my fear is that there will be a time that people will not be advertising on television, radio and the rest of mass media but solely on the social media platforms". Another respondent, Kenny Bola who was interviewed on the 23rd April, 2018 asserts that with the rate at which technology is growing, the use of social media for advertising in Nigeria is just "a drop in the ocean". Put another way, we have not scratched the power of social media advertising. "It is still of a drop in an ocean the way I see, generally, our approach to technology in the recent decade has made things go very fast. The use of online advertising in Nigeria has just started in terms of where we can be, the money right now can tell the future is still bright, but it has not reached its peak yet".

\section{Highly beneficial}

During the analysis of the six interviews conducted by the researcher, it was discovered that the use of social media platforms like Facebook and Instagram is very beneficial to the respondents for online advertising. All of the interviewee attested to the fact that the use of social media has helped to a large extent. According to Kevwe Erutor, interviewed 12th May 2018, social media has helped to promote her business even beyond her circle. Her thoughts are captured below:

Yes, the answer is yes. It actually promotes the project and it has a wider coverage so it's expends not just people within your circle it actually goes as far as showing the entire world, what you actually have to offer.

From the foregoing assertion we see that the social media is very beneficial to this respondent. According to the interviewee, social media has a wider coverage, that is, it transcends distance and time. The advertiser mentions that social media enables her to reach the entire world. The power of the social media to this respondent is enormous. She believes that her project is leveraging on the potentials of the social to enable her reach a wider audience.

Another respondent; Princes Oguejiofor interviewed on the 24th May, 2018 equally revealed that the use of social media for online advertising has been beneficial to her. According to her, a friend introduced her to the use of social media for business purpose and ever since then she has been using it. "Actually, a friend of mine told me about the usage of social media platforms, I use it and it helps me to promote my business". According to the other respondent, Ossia Okey who was interviewed on 
the 20th May, 2018 stated, he has been selling more goods ever since he stated using social media for promoting his services. In fact, he submitted that he makes more sales online compared to face-to-face transaction. "Very well, with social media I have been selling more than I expected, when I check my turn over I weekly, I notice the ones I sold on social media is more than the ones I sell in my shops". Yet another respondent, Rebecca Koatsa, interviewed on the 22nd May, 2018 confirmed that she was introduced to social media by a friend and ever then her business has been growing. "Of course, I was introduced to this social media platform, and since then my business has been expanding and growing".

\section{Preferred/Major advertising medium}

Also, majority of the interviewee argued that social media is their major advertising medium. The preference of social media for advertising may be connected to the reason given by one of the respondents as stated earlier on that the medium affords her the opportunity to reach a wider audience. Rebecca Koatsa, who was interviewed on the 22nd May, 2018 pointed out that the social media is the major medium she uses for advertising. "Well, it's pretty much the major... I make use of it a lot, it is pretty much my major form of advert, so yes every form of promotion is actually done mostly through social media and then we have other ways of interacting with people that are not through social media". From the thought above we can understand that this individual has other means of reaching her clients, but social media is the preferred medium. One of the respondents, ken Bola interviewed on the 23rd April, 2018 (a photographer) opines that their company solely relies on the social media for advertising. "Very, very well; constantly in fact, it's right now one of major advance source of advert for us, it helps us in getting all that we need and it's not products across to our customers".

Yet another thought from the respondent, Ossia Okey interviewed on the 20th May, 2018, elaborates that he solely base his business promotion on the social media. "Considering my field, I have solely based my business on online in terms of social media interactions and all that, that's mainly the platform I use to advertise". Ahmad Amin, a respondent corroborated the preceding submission. He argued that without the social media there will be no business for him. To him, the social media is the ultimate. "Very well, that has been the way forward, without social media or social media advertising; there would be no business for me rather".

The submissions of these individuals point to one thing: the social media is the major advertising medium for their businesses. They gave different opinions as to why they preferred the social media. In an inter- 
view on the 10th April, 2019, Ahmed summarises his feelings on the theme.

It has really been very successful and positive response from most of my clients; in fact at the moment I can tell you that eighty $80 \%$ of my new clients come from my social media platform; this is because they see it and it connects with them, they feel it and it is easier for them, to get access to and they can easily it as the contact me as well just to get the product.

\section{A Referral/Interlinked Medium}

From analysis of the qualitative data from this study, the researcher discovered that majority of the respondents cited that the social media affords them the opportunities to meet persons that are not originally their pages. This ability of the social media to get new referrals for these business persons makes the social media an interlinked media. According to the discoveries from this study, one of the main advantages of the social media is the connection to new referrals and the expansion of client base. My first interviewee, Kewve Eruotor, interviewed on the 12th May, 2018 succinctly gave her views on the power of the social media to connect her to new referrals.

I would go with new referrals and expansion of client base, because when you have a product and someone buys into it, if he likes it, he shows it off on his page; once he or she shows it off on their page, it reaches another set of wider audience which would want to find out if and how this person acquired the product. And the beauty about this is that when you have some key players what we have right now like "Instagram celebrities." Instagram celebrity is someone that tends to have alot of followers or also icons, when i say icon i mean people that tends to influence alot of products because people see them, they admire them, they want to be like them; they want to wear and go places that those people go. If you could actually reach any of these kinds of people; the referral base you will get and the attention you will get is usually massive; on just only one you could get alot; just by that person identifying with you as a brand; you will get alot of referrals. So, I go with avenue for new referrals and expansion of client base.

It is obvious from this elaborate highlight that the social media has the ability to create a wider coverage through referrals. According to this respondent, when a potential client likes her Instagram page, the client automatically refers her product to the persons on her friend list. Particularly, the Instagram celebrities are so vital and powerful in this regard. This interviewee postulated that Instagram celebrities are individuals that have many followers Instagram. Furthermore, these celebrities tend to in- 
fluence potential consumer with their ways of life. In other words, Instagram celebrities have the capability to expand a company's client base. Rebecca Koatsa, interviewed on the 22nd May 2018 attested that the referral power of the social media affords the opportunity to interface more with her client. "Well, I would say it creates an opportunity for me to interface with my clients more, because it gives me the opportunity to get more references, get more information about what my clients feel about the product and it helps me to remodel or reshape my products best suit my clients and get more business". In other words, the social media also helps the latter participant to get feedback from her clients. This is the interactivity feature of the social media. It allows two-way communication between clients and business persons. Yet another participant affirmed this referral theme: "Well for me, an avenue for new referrals and expansion of client base is the ultimate, in the sense that if I have enough referrals, my business grows and I make more money".

The foregoing assertion brings us to the need to mention that the social media is highly interactive/interlinked medium. The media allows the free flow of information across board. It is very easy for a client or business owner to share content from a particular medium, say Instagram to other platforms like Facebook and Twitter. The sharing of contents across platforms enables a business to reach a large audience. That is why it has been argued that account pages of different media are not just constructed by the owner of the account, but profile are being constructed today by both the owner of the account and their friends/followers. For instance, if an individual decides to share a picture on his Facebook account and he tags me, automatically my Facebook page will further display the picture which he tagged me to. Also, my friends on Facebook will get to view the picture. So, most social media platforms have add-ons that enable user cocreate pages.

\section{Poor Infrastructures}

Despite the huge potentials of social media in advertising, there are downsides to the use of social media for advertising. Findings from the analysis of data showed that social media could be a two-edged sword. According to one of the interviewee Ahmad Amin, "I would rate it high, very high, because it has the capability to run down your business and at the same time, has the power to boost your business". From this thought, the participant acknowledges the merits and demerits of social media.

The prominent challenge of the social media advertising that emanated from my data analysis is the lack of internet connection or data. Almost all the interviewees assert that the most challenging challenge of 
using social media for advertising is poor internet connection. A participant put his thought thus: "It has to do with the internet usage, alot of people do not have that much access to internet, and Lack of the access to internet hinders it; and the understanding and usage of social media platform". Another respondent, Ossai Okey corroborated this latter thought. "It is the same with the problems in Nigeria; we talk about high cost of internet, power issues, internet availability, we even thank God now that our phones people can access internet. Like five to ten years ago, for you to get internet access, you have to go and pay for browsing time at cyber cafes and the likes of hanging micro wave radios etc, but now thank God for $3 \mathrm{G}$ and $4 \mathrm{G}$ network by tier 1 providers. The future is bright".

Other minor challenges that evolved from the findings are lack of technical know-how to use the social media, and the activities of fraudsters. It was discovered that the participants still believe that a good technical know-how of the social media is crucial to achieving the full potential of the medium. "Know how - Awareness on how to use the social media platform and also how to reach the people who are experts to explain how to use most if the features on these platforms". The social media is readily available for any individual to use, but the knowledge of how to use it is essential. Another respondent opines thus: "Some people are still yet to grasp the whole idea of how they can use it to get across their prospective client". This final observation from one of the interviewees, Ken Bola who was interviewed on the 23rd April, 2018, gives us a gist of the whole challenges; both minor and major challenges:

No matter how effective or fast we are approaching this, we can't rule out the fact that we are still a developing world, as you know a country like Nigeria still has some rural areas where they do not have access to electricity not to talk about the modern technology that will enhance online advertising access to internet use. So those are some challenges and we hope the government can look into that we could talk about education the number of literate people compared to the illiterate, there is still a wide gap, especially with the youths and younger generation access to education and the facilities to engage the use of the internet.

This study aims to assess the use of social media for online advertising in Nigeria. From the qualitative analysis of data, it has been revealed that social media advertising is finding its place among Nigerian businesses. Despite the merits of social media advertising, the study found that there are downsides to the use of social media for advertising. The themes discussed above are the major discoveries from the study. Findings 
from the quantitative study will further strengthen and reinforce the findings from the qualitative study.

GRAPHICAL ANALYSIS OF QUANTITATIVE DATE

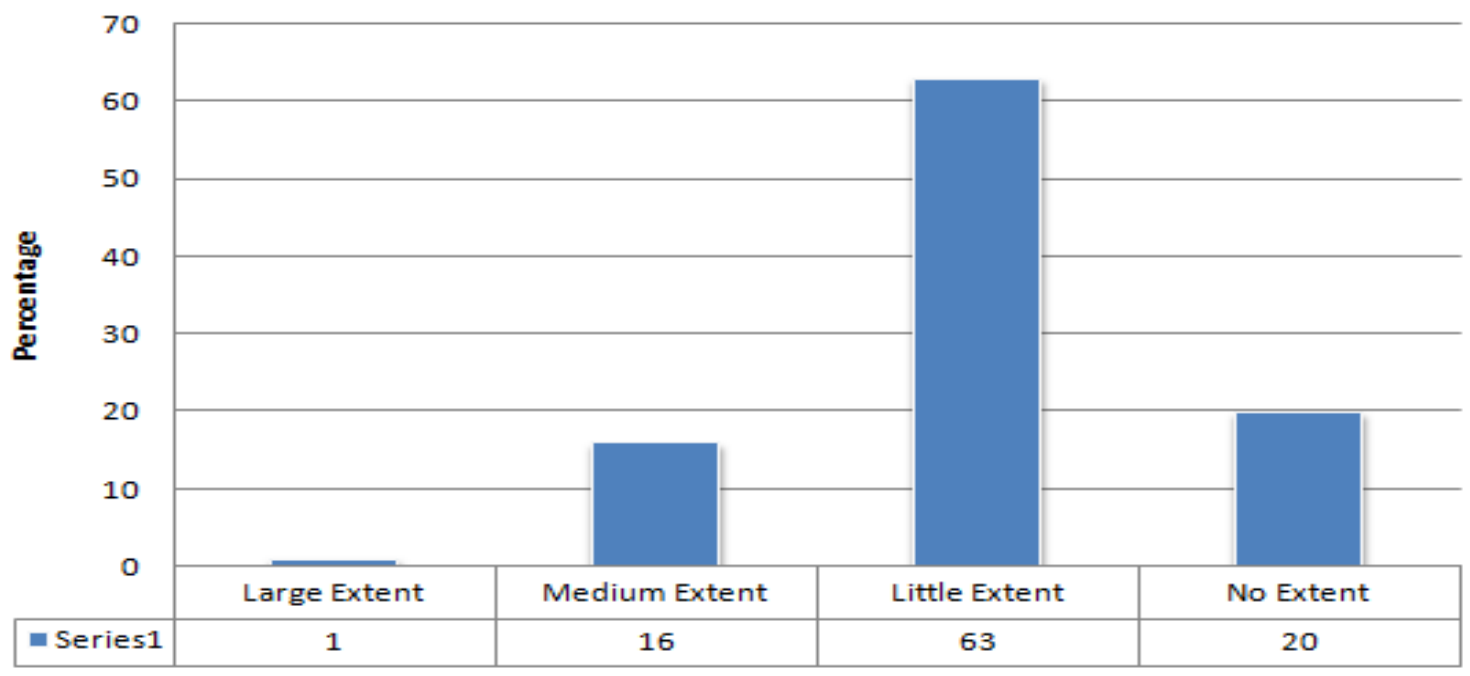

The extent social media are used by Nigerian companies to advertise products and services

The benefit of online advertising on businesses

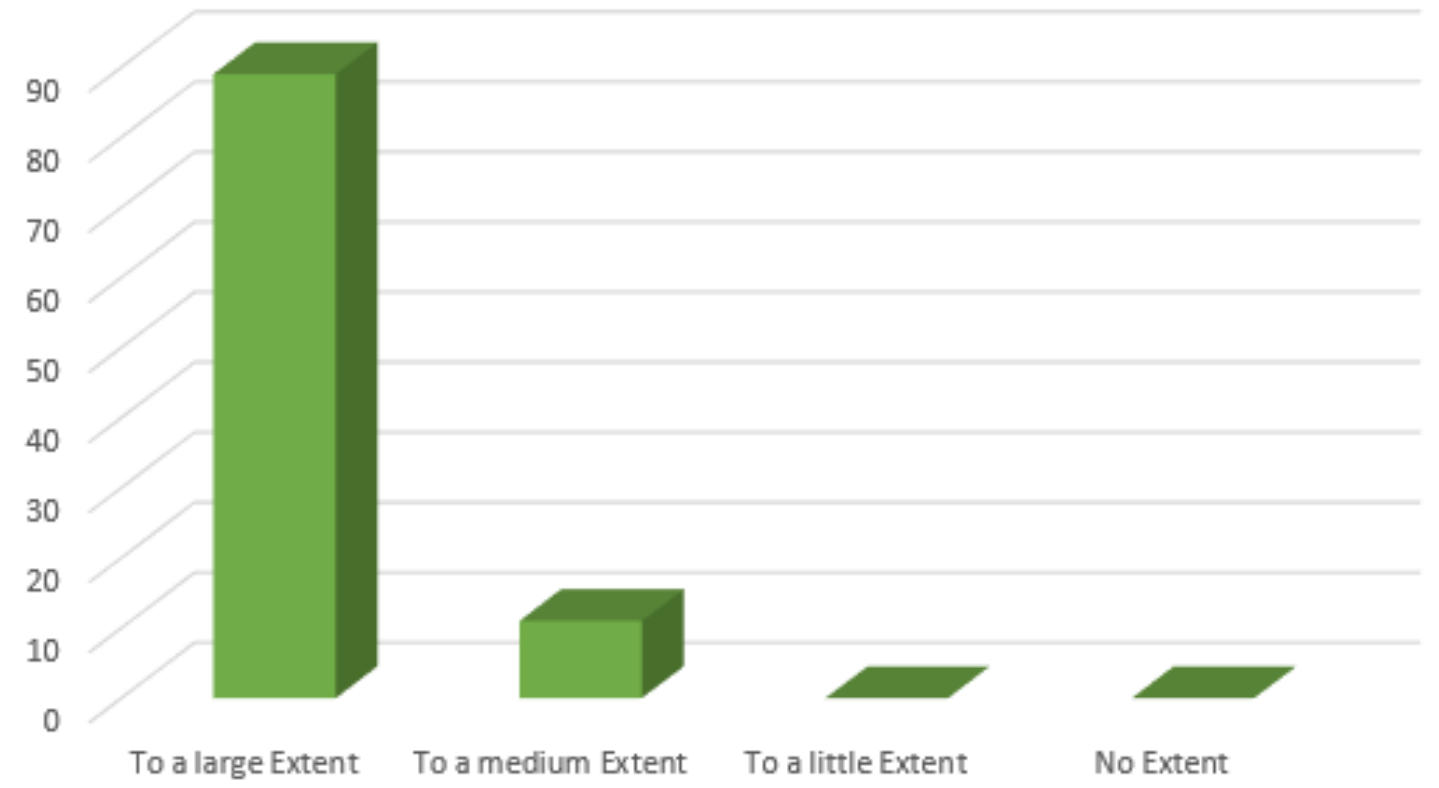


Galactica Media: Journal of Media Studies. 2020. No 2 | ISSN: 2658-7734

New Media and Human Communication | Doi: 10.46539/gmd.v2i2.62

\section{Online Advertising Advantages with the most impact on Businesses}
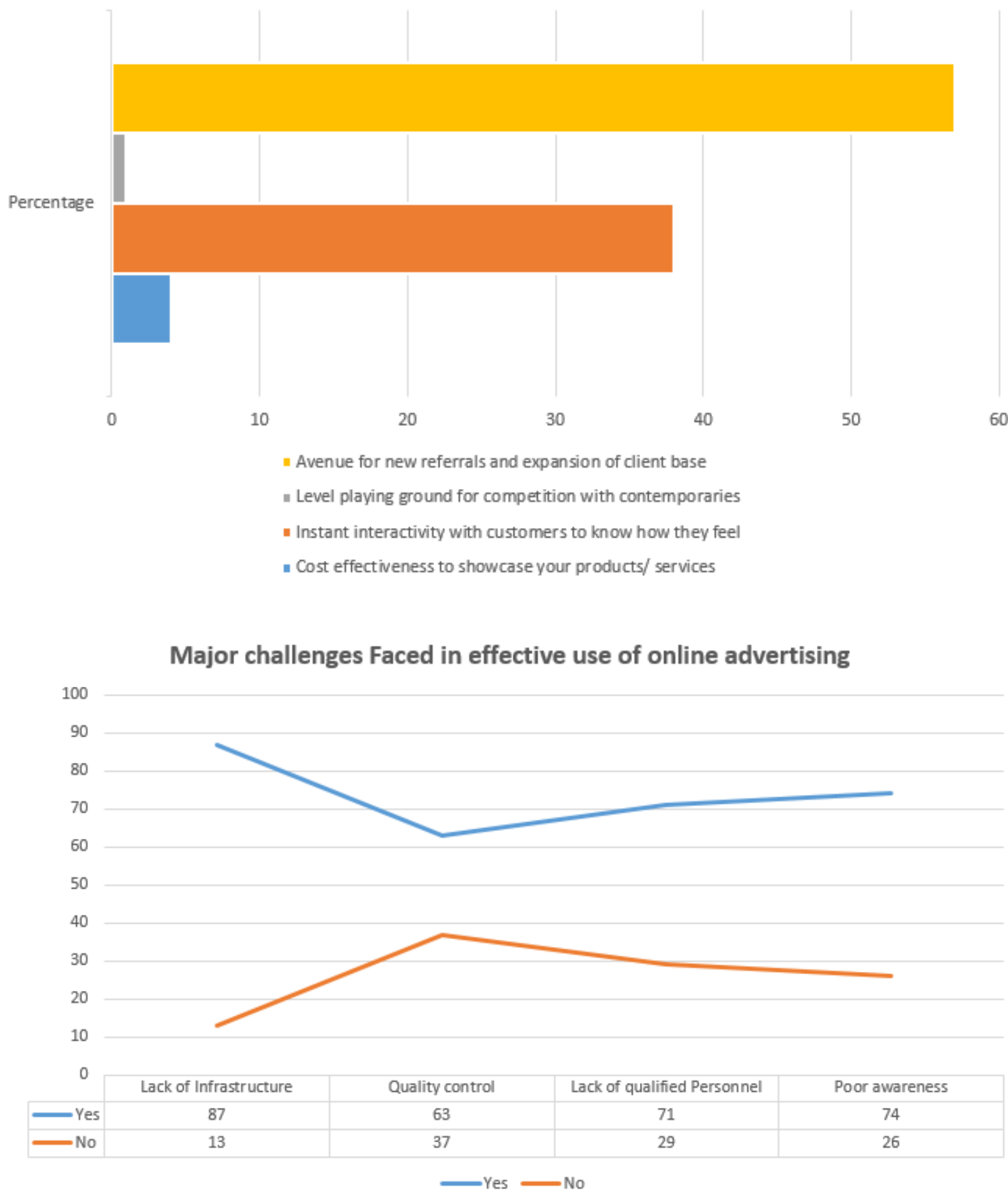
Method to Overcome Present Challenges Faced by effective online advertising

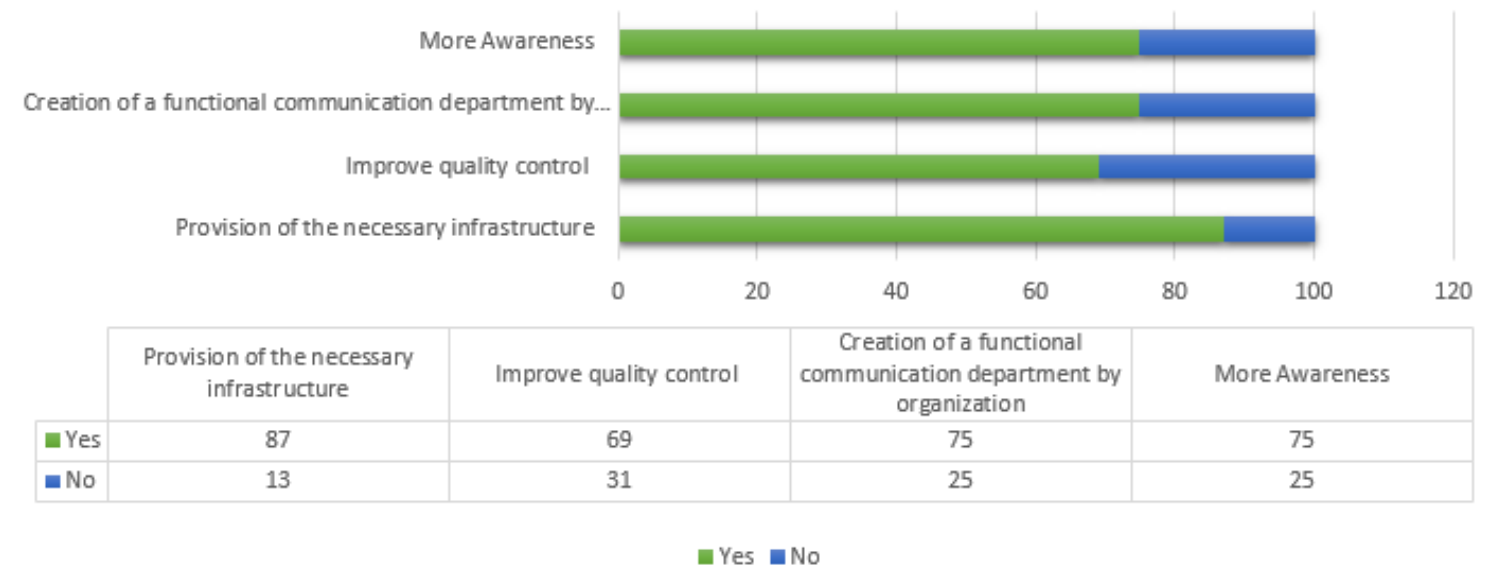

\section{DISCUSSION OF FINDINGS}

After a thorough analyses of both qualitative and quantitative data emanating from the survey and semi structured interviews, the study reveals that online advertising in Nigeria through platforms like Facebook and Instagram are not utilized as they should, despite obvious fact that a large sum of Nigerians are active users of these platforms making them already potential customers. Similarly, this illumination aligns with Endwell (2012) established that respondents are aware of the use of social media in advertising but only a few organizations that advertises on the platforms. Another study which supports this result is that of Folaranmi (2013) which says that "Nigeria is not Lagging behind when it among other social media users."

The work also reveals that customers expects to see more of their favorite brands advertise on social media, so they can be able to advice the brands how best to improve, this clearly is in line with what Endwell, Terna and Nyekwere (2013, p.130) said "From the foregoing finding, one can deduce that consumers expect a dialogue in social media, in which brands listen to what they have to say rather than simply pushing promotional marketing messages to them without taking into account what they think, feel, and want." The study also discovered that when it comes to what aspects social media advertisements are mostly targeted, majority of the respondents admitted that online advertising through social media accelerate instant decision making in keying to a product or service. Again, the work of Endwell, Terna and Nyekwere (2013) also brought up a discovery which is similar to the research discovery; theirs states that social 
media advertising help make buying decisions either on the customer's accord or through recommendations by reviews or by their trusted friends. Singh (2012) also stated that his study also found out that online advertisements of brands and celebrity endorsement influences the behaviour of the potential buyer.

Another finding the study discovered is that amongst the uncountable benefits Nigerian businesses can benefit from online advertising like direct access to customers, an open forum to communicate with them and hear their views with regards to your brand, a level playing ground with contemporaries; majority of the respondents that were business owners selected an avenue for new referrals and expansion of client base. This simply means that

Findings from this study have contributed to the body of knowledge in the theory which anchored this study; Diffusion of Innovation Theory, revealed that alot of Nigerian business or brands are at different stages of using these platforms while some businesses already make use it as their main advertising platform, some are just beginning to accept the new concept and type of audience, some other businesses just register their presence in it and are not so active; while there are still some that do not even make us of it at all due to certain circumstances like lack of infrastructure, no professional hand to assist in running the arm of the business, ignorance of what to do or just under minding the potency of these new type of adverting and marketing. They are all at different stages of accepting and utilizing this innovation. Similarly, Nyekwere (2009, p. 22) also revealed in his study that "the success for any new innovation critically depends on the level of awareness, interest and adoption that is given to that innovation".

\section{CONCLUSION}

From this study, it is very obvious that Nigerian businesses are not doing enough to utilize the use of social media platforms such as Facebook and Instagram as advertising platforms. There is evidence however that the few businesses that are already making use of it are benefiting tremendously, gaining a wider base of audience, not just locally but on a global scale; and massive boost in terms of sales or patronage. The consumers on the other hand are rapidly increasing in the adoption of these innovations, clearly showing their desire, for their favourite products and brands to become more personal with them. Creating a connection where they can contribute and make the brands serve them better. This automatically creates an already willing market for the businesses to explore. 
Thus, this work is an eye opener for Nigerians who are into business and for those aspiring to start up one in future, which they should stop, wasting too much time the social media for just having fun and social activities, but start utilizing the various platforms to advertise their brands or products and get more closer to their customers.

\section{RECOMMENDATIONS}

Based on the findings, the following recommendations were made:

i. Business owners or managers in Nigeria should change their perception about the social media as just a platform for social or fun activities, not really for serious individuals or business, but to start seeing it as a platform they can utilize and benefit from tremendously.

ii. There is need for institutions of learning to inculcate social media studies; and even branch it out into so many specializations like advertising, public relations, news gathering and reporting etc, into their curriculum of study. Young scholars need to be guided to the right path of this not new but yet still so broad and explore it, in order to expand its vast and untapped aspects for the benefit of not just the Nation but the world at large.

iii. There is need for the government to provide basic amenities like constant electricity and policies that will make internet providers to cut down on prices of internet access.

iv. The regulatory agency, Consumer Protection Council put together by the Government needs to put in more effort in monitoring Nigerian companies advertising on the social media. This agency should serve as a guide for consumers to be informed on which adverts are real and verified, and those that are not. Nigerian businesses will apply, get inspected in person and then registered on the agency's official media platforms. This will also enhance accountability, control and help in the eradication of fraudsters on the social media.

v. Businesses in Nigeria should consider employing professionals to handle their social media pages. In order to get the best out of these platforms, it is important to get someone with some level of knowledge and training in the field. The expertises will help guide the business in making the right type of discussions that can improve the business. 
Adikesavan, T.A. (2014). Management Information System Best Practices and Applications in Business. Delhi: PHI Learning Private Limited.

Alexander, B. (2008). Social Networking in Higher Education. In R. N. Katz (Eds.), The tower and the cloud: Higher education in the age of cloud computing (pp. 197201). EDUCAUSE.

Amarashinghe, A, (2010). What motivate people to participate in social media? Retrieved from: http:// www.Socialmediiatoday.com/index.php?q=SMC/190 499

Amin, A. (2018, April 10). Semi-Structured Interviewed.

Anaeto, S.G., Onabanjo, O.S. \& Osifeso, T.B. (2008). Models and Theories of Communication. African Renaissance Books: Bowie, Maryland.

Andreas, M. K. (2015). Social Media, the Digital Revolution, and the Business of Media. International fournal on Media Management, 17(4), 197-199. Retrieved from: Doi: $\underline{10.1080 / 14241277.2015 .1120014 .}$.

Arens, W. (2008). Contemporary Advertising (10th ed). New Delhi: Tata McGraw Hill Publishing Company Limited.

Asemah, E. S. \& Edegoh, L. O. (2012). New Media Political Advertising in Nigeria: Prospects and Challenges. African Research Review, 6(4), 248-265. DOI: 10.4314/ afrrev.v6i4.17

Baker, S.E., \& Edward, S. (N.D). National Centre for Research Methods Review Paper: How many qualitative interviews is enough? Retrieved from: www.LINKEDIN \%20PAPERS/how_many_interviews.pdf

Belch, G. E. \& Belch, M. A. (2001). Advertising and promotion: an integrated marketing communications perspectives (5th ed.). Boston: McGraw-Hill

Bola, K. (2018, April 23). Semi-Structured Interviewed.

Briggs, R. \& Hollis, N. (1997). Advertising on the Web: Is there Response before Click Through, Journal of Advertising Research, 37(2), 34-45.

Brook, A. (2010). Facebook and social media ads work well together. Survey by Nielsen and Facebook. Retrieved from: http://www.billhartzer.com

Bush, A. J. \& Bush, V. (1998). Advertiser Perceptions of the Internet as a Marketing Communication Tool. Journal of Advertising Research, 38(2), 17-27.

Cartellieri, C., Parsons, A. J., Rao, V. \& Zeisser, M. P. (2000) The real impact of Internet advertising Competition on Price, Quality, and Distribution. Marketing Science, 19 (1).

Chaykowski, K. (2016). Instagram reaches 600 million monthly users, doubling in size in two years. Forbes news. Retrieved from:

https://www.forbes.com/sites/kathleenchaykowski/2016/12/15/instagramreaches-600-million-monthly-users-doubling-in-size-in-two-years/ $\# 1 \mathrm{f} 213 \mathrm{~b} 151 \mathrm{~b} 24$ 
Choi, S. M. \& Rifon, M. J. (2002). Antecedents and Consequences of Web Advertising Credibility. Fournal of Interactive Advertising, 3(1), 12-24. Doi: $10.1080 / 15252019.2002 .10722064$

Cronin, A.M. (2000), Advertising and Consumer Citizenship. New York: Routledge.

Dominick, J. R. (2009). Dynamics of mass communication: media in the digital age (10th ed.). Boston: McGraw-Hill.

Dreze, X. \& Zufryden, F. (1998). Is Internet Advertising ready For Prime Time. fournal of Advertising Research, 38(3), 7-18.

Ducaffee, R. H. (1996). Advertising value and advertising on the web. Fournal of Advertising Research. 36(5), 21-35

Dunay, P. \& Krueger, R. (2010). Facebook marketing for dummies. Indianapolis-Indiana: Wiley Publishers.

Eruotor, K. (2018, May 12). Semi-Structured Interviewed.

Falah, M.B. (2014). Online Advertising, also called online marketing or internet advertising. Create space independent publishing platform.

https://www.amazon.com/Online-advertising-called-marketing-Internet/dp/ 150316196X

Financial Nigeria (2016). Facebook records 16 million active users in Nigeria. Retrieved from: http://www.financialnigeria.com/facebook-records-16-million-activeusers-in-nigeria-news-344.html\#sthash.YHQoPEZv.dpuf

Folarin, B. (2005). Theories of mass communication: An introductory text. Ibadan: Stirling-Horden

Gallagher, K., Foster, K.D. \& Parsons, J. (2001). The Medium is not the Message: Advertising Effectiveness and Content Evaluation in Print and or the Web. Fournal of Advertising Research, 41(4), 57-70. Doi: 10.2501/JAR-41-4-57-70

Gordon, M. E. \& Lima-Turner, K. D. (1997). Consumer attitudes towards internet advertising: a social contract perspective. Retrieved from:

www.emeraldinsight.com/casestudieshtm

Goyal, S. (2013). Advertising on social media. Retrieved from: http://sjournals.com/index.php/SJPAS/article/view/551

Hoffman, D. L. \& Novak, T. P. (1996). Marketing in Hypermedia Computer Mediated Environments: Conceptual Foundations. Fournal of Marketing, (3), 50-68.

Hogben, G. (2007). Security Issues and Recommendations for Online Social Networks, ENISA Position Paper (1). Retrieved from: http://w.w.w.enisa.europa.eu/doc/pdf/ deliverables/enisa pp social networks.pdfhttps://newsroom.fb.com

Hwang, J. et al., (2003). Corporate web sites as advertising: an analysis of function, audience, and message strategy. Journal of Interactive Advertising. 3(2), 10-23. Doi: $10.1080 / 15252019.2003 .10722070$

Koatsa, R. (2018, May 22). Semi-Structured Interviewed. 
Korgaonkar, P., Silverbutt, R. \& O’Leary, B. (2001). Web advertising and Hispanic. fournal of Consumer marketing, 18(2), 134-152. Doi: 10.1108/0 7363760110386009

Li, H., Daughterty, T. \& Biocca, F. (2002). Impact of 3-D advertising on product knowledge brand attitude, and purchase intention: the mediating role of presence. Fournal of Advertising, 31(3), 43-57. Doi: 10.1080/00 913367.2002 .10673675

Lisica, I., Jesic, M. \& Neskovic, E. (2012). Marketing Innovation through Digital Advertising. Belgrade: Innovative Management \& Business Performance.

Lombard, M. \& Snyder-Duch, J. (2001). Interactive advertising and presence: a framework. Journal of Interactive Marketing, 1(2), 56-65. Doi: 10.1080/15252019.2001.10722051

Lynch, J. G. \& Ariely, D. (2000). Wine Online: Search Costs and Mediated Environments: Conceptual Foundations. Journal of Marketing, 19(1), 83-103. Doi: 10.1287/mksc.19.1.83.15183

MaQuail, D. (2011). McQuail's Mass communication theory. London: Sage.

Nigerian Communications Commission, (2017). Stakeholders Information on Industry Statistics report. Retrieved from https://www.ncc.gov.ng/stakeholder/statisticsreports/industry-overview\#view-graphs-tables-5

Nyekwere, O. (2009). Influnce of New Media Technologies in Broadcasting: A Study of Television Stations in Port-Harcourt Metropolis. Nsukka, University of Nigeria.

O'Connor, J. \& Galvin, E. (2001). Marketing in the digital age. (2nd.Ed.). Essex: Pearson Education

O’Shaughnessy, J. \& O’Shaughnessy, N.J. (2003). Persuasion in Advertising. New York: Routledge.

Office of Communications (OFCOM) Research Document. (2008). Social Networking: A quantitative research report in to attitudes; behaviours and use.

Oguejiofor, P. (2018, May 24). Semi-Structured Interviewed.

Ojobor, I. J. (2002). Mass communication theories. In C.S. Okunna, (Eds.), Teaching mass communication: A multi-dimensional approach (pp. 1-26). Enugu: New Generation Books.

Okey, O. (2018, May 20). Semi-Structured Interviewed.

Palanisamy, R. \& Wong, S. A. (2003). Impact of Online Consumer characteristics on Web- based Banner Advertising Effectiveness. Global Journal of Flexible Systems Management, 4(1), 15-25.

Pavlou, P. A. \& Stewart, D. W. (2000). Measuring the Effects and Effectiveness of Interactive Advertising: A Research Agenda. Journal of Interactive Advertising, 1(1), 61-77, Doi: 10.1080/15 252 019.2000.10722 044

Qimei, C. \& William D. W. (1999). Attitude toward the Site. Fournal of Advertising Research, 39(5), 27.

Redbridge Marketing. (2008). Social Network Marketing: The Basics. 
Rodgers, S. \& Thorson, E. (2000). The interactive advertising model; how users perceive and process online ads. Fournal of Interactive Advertising, 1(1), 41-60. Doi: $10.1080 / 15252019.2000 .10722043$

Schlosser, A. E., Shavitt, S. \& Kanfer, A. (1999). Survey of internet users' attitude towards internet advertising. Fournal of Interactive Marketing, 13(3), 34-54.

Taylor H. (2016). If social networks were countries, which would they be. World economic forum: Social Media. Retrieved from:https://www.weforum.org/agenda/2016/04/ facebook-is-bigger-than-the-worlds-largest-country/

Taylor Nelson Sofres (TNS), Teenage Research unlimited (TRU) and Marketing Evolution. (2007). Never Ending Friending - A Journey in to Social Networking. Inc.

Toivo, S. (2012). Social Media- The New Power of Political Influence. Helsinki: Centre for European Studies.

Young Adult Library Services Association (YALSA). (2008). Teens and Social Networking in School and Public libraries: A Toolkit for Librarians and Library workers.

Zarrella, D. \& Zarrella, A. (2011). The Facebook marketing book. North SebastopolUkraine: O'Reily Media.

Список литературы

Adikesavan, T.A. (2014). Management Information System Best Practices and Applications in Business. Delhi: PHI Learning Private Limited.

Alexander, B. (2008). Social Networking in Higher Education. In R. N. Katz (Eds.), The tower and the cloud: Higher education in the age of cloud computing (pp. 197201). EDUCAUSE.

Amarashinghe, A, (2010). What motivate people to participate in social media? Retrieved from: http:// www.Socialmediiatoday.com/index.php?q=SMC/190 499

Amin, A. (2018, April 10). Semi-Structured Interviewed.

Anaeto, S.G., Onabanjo, O.S. \& Osifeso, T.B. (2008). Models and Theories of Communication. African Renaissance Books: Bowie, Maryland.

Andreas, M. K. (2015). Social Media, the Digital Revolution, and the Business of Media. International fournal on Media Management, 17(4), 197-199. Retrieved from: Doi: $\underline{10.1080 / 14241277.2015 .1120014 .}$.

Arens, W. (2008). Contemporary Advertising (10th ed). New Delhi: Tata McGraw Hill Publishing Company Limited.

Asemah, E. S. \& Edegoh, L. O. (2012). New Media Political Advertising in Nigeria: Prospects and Challenges. African Research Review, 6(4), 248-265. DOI: 10.4314/ afrrev.v6i4.17

Baker, S.E., \& Edward, S. (N.D). National Centre for Research Methods Review Paper: How many qualitative interviews is enough? Retrieved from: www.LINKEDIN \%20PAPERS/how_many_interviews.pdf 
Belch, G. E. \& Belch, M. A. (2001). Advertising and promotion: an integrated marketing communications perspectives (5th ed.). Boston: McGraw-Hill

Bola, K. (2018, April 23). Semi-Structured Interviewed.

Briggs, R. \& Hollis, N. (1997). Advertising on the Web: Is there Response before Click Through, Journal of Advertising Research, 37(2), 34-45.

Brook, A. (2010). Facebook and social media ads work well together. Survey by Nielsen and Facebook. Retrieved from: http://www.billhartzer.com

Bush, A. J. \& Bush, V. (1998). Advertiser Perceptions of the Internet as a Marketing Communication Tool. Journal of Advertising Research, 38(2), 17-27.

Cartellieri, C., Parsons, A. J., Rao, V. \& Zeisser, M. P. (2000) The real impact of Internet advertising Competition on Price, Quality, and Distribution. Marketing Science, 19 (1).

Chaykowski, K. (2016). Instagram reaches 600 million monthly users, doubling in size in two years. Forbes news. Retrieved from:

https:/www.forbes.com/sites/kathleenchaykowski/2016/12/15/instagramreaches-600-million-monthly-users-doubling-in-size-in-two-years/ $\# 1 \mathrm{f} 213 \mathrm{~b} 151 \mathrm{~b} 24$

Choi, S. M. \& Rifon, M. J. (2002). Antecedents and Consequences of Web Advertising Credibility. Fournal of Interactive Advertising, 3(1), 12-24. Doi: $10.1080 / 15252019.2002 .10722064$

Cronin, A.M. (2000), Advertising and Consumer Citizenship. New York: Routledge.

Dominick, J. R. (2009). Dynamics of mass communication: media in the digital age (10th ed.). Boston: McGraw-Hill.

Dreze, X. \& Zufryden, F. (1998). Is Internet Advertising ready For Prime Time. fournal of Advertising Research, 38(3), 7-18.

Ducaffee, R. H. (1996). Advertising value and advertising on the web. Fournal of Advertising Research. 36(5), 21-35

Dunay, P. \& Krueger, R. (2010). Facebook marketing for dummies. Indianapolis-Indiana: Wiley Publishers.

Eruotor, K. (2018, May 12). Semi-Structured Interviewed.

Falah, M.B. (2014). Online Advertising, also called online marketing or internet advertising. Create space independent publishing platform.

https://www.amazon.com/Online-advertising-called-marketing-Internet/dp/ 150316196X

Financial Nigeria (2016). Facebook records 16 million active users in Nigeria. Retrieved from: http://www.financialnigeria.com/facebook-records-16-million-activeusers-in-nigeria-news-344.html\#sthash.YHQoPEZv.dpuf

Folarin, B. (2005). Theories of mass communication: An introductory text. Ibadan: Stirling-Horden 
Gallagher, K., Foster, K.D. \& Parsons, J. (2001). The Medium is not the Message: Advertising Effectiveness and Content Evaluation in Print and or the Web. Fournal of Advertising Research, 41(4), 57-70. Doi: 10.2501/JAR-41-4-57-70

Gordon, M. E. \& Lima-Turner, K. D. (1997). Consumer attitudes towards internet advertising: a social contract perspective. Retrieved from: www.emeraldinsight.com/casestudieshtm

Goyal, S. (2013). Advertising on social media. Retrieved from: http://sjournals.com/index.php/SJPAS/article/view/551

Hoffman, D. L. \& Novak, T. P. (1996). Marketing in Hypermedia Computer Mediated Environments: Conceptual Foundations. Journal of Marketing, (3), 50-68.

Hogben, G. (2007). Security Issues and Recommendations for Online Social Networks, ENISA Position Paper (1). Retrieved from: http://w.w.w.enisa.europa.eu/doc/pdf/ deliverables/enisa pp social networks.pdfhttps://newsroom.fb.com

Hwang, J. et al., (2003). Corporate web sites as advertising: an analysis of function, audience, and message strategy. Fournal of Interactive Advertising. 3(2), 10-23. Doi: $10.1080 / 15252019.2003 .10722070$

Koatsa, R. (2018, May 22). Semi-Structured Interviewed.

Korgaonkar, P., Silverbutt, R. \& O’Leary, B. (2001). Web advertising and Hispanic. Journal of Consumer marketing, 18(2), 134-152. Doi: 10.1108/07363760110386009

Li, H., Daughterty, T. \& Biocca, F. (2002). Impact of 3-D advertising on product knowledge brand attitude, and purchase intention: the mediating role of presence. Fournal of Advertising, 31(3), 43-57. Doi: 10.1080/00 913367.2002 .10673675

Lisica, I., Jesic, M. \& Neskovic, E. (2012). Marketing Innovation through Digital Advertising. Belgrade: Innovative Management \& Business Performance.

Lombard, M. \& Snyder-Duch, J. (2001). Interactive advertising and presence: a framework. Journal of Interactive Marketing, 1(2), 56-65. Doi: 10.1080/15252019.2001.10722 051

Lynch, J. G. \& Ariely, D. (2000). Wine Online: Search Costs and Mediated Environments: Conceptual Foundations. Fournal of Marketing, 19(1), 83-103. Doi: 10.1287/mksc.19.1.83.15183

MaQuail, D. (2011). McQuail's Mass communication theory. London: Sage.

Nigerian Communications Commission, (2017). Stakeholders Information on Industry Statistics report. Retrieved from https://www.ncc.gov.ng/stakeholder/statisticsreports/industry-overview\#view-graphs-tables-5

Nyekwere, O. (2009). Influnce of New Media Technologies in Broadcasting: A Study of Television Stations in Port-Harcourt Metropolis. Nsukka, University of Nigeria.

O'Connor, J. \& Galvin, E. (2001). Marketing in the digital age. (2nd.Ed.). Essex: Pearson Education

O’Shaughnessy, J. \& O’Shaughnessy, N.J. (2003). Persuasion in Advertising. New York: Routledge. 
Office of Communications (OFCOM) Research Document. (2008). Social Networking: A quantitative research report in to attitudes; behaviours and use.

Oguejiofor, P. (2018, May 24). Semi-Structured Interviewed.

Ojobor, I. J. (2002). Mass communication theories. In C.S. Okunna, (Eds.), Teaching mass communication: A multi-dimensional approach (pp. 1-26). Enugu: New Generation Books.

Okey, O. (2018, May 20). Semi-Structured Interviewed.

Palanisamy, R. \& Wong, S. A. (2003). Impact of Online Consumer characteristics on Web- based Banner Advertising Effectiveness. Global fournal of Flexible Systems Management, 4(1), 15-25.

Pavlou, P. A. \& Stewart, D. W. (2000). Measuring the Effects and Effectiveness of Interactive Advertising: A Research Agenda. Journal of Interactive Advertising, 1(1), 61-77, Doi: 10.1080/15 252 019.2000.10722 044

Qimei, C. \& William D. W. (1999). Attitude toward the Site. fournal of Advertising Research, 39(5), 27.

Redbridge Marketing. (2008). Social Network Marketing: The Basics.

Rodgers, S. \& Thorson, E. (2000). The interactive advertising model; how users perceive and process online ads. Fournal of Interactive Advertising, 1(1), 41-60. Doi: $10.1080 / 15252019.2000 .10722043$

Schlosser, A. E., Shavitt, S. \& Kanfer, A. (1999). Survey of internet users' attitude towards internet advertising. Journal of Interactive Marketing, 13(3), 34-54.

Taylor H. (2016). If social networks were countries, which would they be. World economic forum: Social Media. Retrieved from:https://www.weforum.org/agenda/2016/04/ facebook-is-bigger-than-the-worlds-largest-country/

Taylor Nelson Sofres (TNS), Teenage Research unlimited (TRU) and Marketing Evolution. (2007). Never Ending Friending - A Journey in to Social Networking. Inc.

Toivo, S. (2012). Social Media- The New Power of Political Influence. Helsinki: Centre for European Studies.

Young Adult Library Services Association (YALSA). (2008). Teens and Social Networking in School and Public libraries: A Toolkit for Librarians and Library workers.

Zarrella, D. \& Zarrella, A. (2011). The Facebook marketing book. North SebastopolUkraine: O'Reily Media. 